\title{
Development of Novel Products from Osmo-Dried Apples: Apple Choco Shots and Apple Pie
}

\author{
Babita Sharma, Devina Vaidya and Anil Gupta* \\ Department of Food Science and Technology, Dr YS Parmar University of Horticulture and \\ Forestry, Nauni, Solan HP-173230, India \\ *Corresponding author
}

\section{A B S T R A C T}

\begin{tabular}{|c|}
\hline Keywords \\
\hline $\begin{array}{l}\text { Novel products, } \\
\text { Apple pops, Apple } \\
\text { choco shots, Apple } \\
\text { pie, Energy value }\end{array}$ \\
\hline Article Info \\
\hline $\begin{array}{l}\text { Accepted: } \\
12 \text { August } 2018 \\
\text { Available Online: } \\
\text { 10 September } 2018\end{array}$ \\
\hline
\end{tabular}

Novel products were prepared from apple fruits by using osmotic dehydration. In the present study osmo-dried apple pops and rings were developed from 'Golden delicious' apples and further utilized for the development of novel products viz. apple choco shots and apple pie. The technology for osmo-dried apple pops with diameter of $28 \mathrm{~mm}$ and apple rings with thickness of $0.5 \mathrm{~cm}$, followed by dipping in sugar syrup and honey for four hours at $50^{\circ} \mathrm{C}$ was optimized. Honey osmo-dried apple pops and rings were found better in terms of quality and sensory characteristics and having less water activity. Further, the novel products were prepared from osmo-dried apple pops and rings i.e. apple choco shots and apple pie. Honey being rich in phenols and flavonoids result in better antioxidant activity with excellent energy value of the developed products. The apple choco shots and apple pie prepared from honey osmo-dried pops and rings were found better in quality with energy value of $430.09 \mathrm{Kcal} / 100 \mathrm{~g}$ and $260.74 \mathrm{Kcal} / 100 \mathrm{~g}$ respectively. Thus, the developed technology can be commercially explored at industry level for the production of quality osmo-dried apple pops, apple rings, apple choco shots and apple pie.

\section{Introduction}

Apple (Malus domestica) is one of the most important temperate fruit of Himachal Pradesh and constitutes about 49 per cent of the total crop area under this fruit crop. It is cultivated in an area of 1, 10, 679 ha with a production of 7, 77, $126 \mathrm{MT}$ and productivity of 7.02 MT/ha (Anonymous, 2016). With great nutritional value apple occupies a significant place in the nutritional produce of the state and plays a vital role in economy of the people. Apple contains lots of nutrients including vitamin $\mathrm{C}$, potassium and fibre (Boyer and Liu, 2004). Apples are processed into a variety of products, but by far the largest volume of processed apple products is in the form of juice. Apple juice, pulp and concentrate are the major processed products in the market. However, the novel products from the apple fruits are lacking.

Apples are prone to qualitative and quantitative losses after harvest and as high as $17 \%$ losses may occur during postharvest operations and storage (Shah et al., 2002). The 
drying can be the best option to avoid losses and to increase the shelf life of apples (Famurewa et al., 2006). Sun drying is a common method among growers followed to produce sun dried apple rings commonly known as Sakori but the quality of sun dried apples is very poor. Dried fruits are beneficial to human health because they are rich sources of vitamins, minerals, antioxidants and especially fibres (including soluble fibres) due to their concentration during processing (Farzaneh et al., 2011).

Further, the osmotic dehydration (sugar syrup) is a better drying method and is considered as a preservation method that provides high quality product by means of water removal without phase change (Lenart, 1996). However, keeping in view the health concern of the consumers, honey can be used as replacer of sugar in hypertonic solution which can give a better osmo-dried product with good nutritional value.

The apple rings prepared with traditional technology are not fetching better price due to their appearance and taste. Therefore, the novel products development from dried apple by using them in bakery and confectionary can be a profitable venture. In confectionary, chocolate are favorite among children as well as young generation and is a highly nutritious energy source, with a fast metabolism and good digestibility (Pedro et al., 2006). Chocolate can be utilized for the development of novel and children friendly apple products like apple chocho shots by filling with dried apples and apple pie by filling stewed apples can be another novel product.

Thus, keeping in view the demand of innovative products in the market and huge scope of using apple fruits, the present study was conducted to develop consumer's friendly novel products from apple and osmo dried apples.

\section{Materials and Methods}

\section{Raw materials}

The apple fruits (Golden delicious) harvested at optimum maturity was procured from the local market. Raw material was purchased from the local market and multifloral honey was procured from the local farm, Dr YS Parmar University of Horticulture and Forestry, Nauni, Solan, H.P used for conducting this study.

\section{Methods and procedure}

The dipping time for apple pops and apple rings was optimized initially by selecting firm ripe fruits followed by washing, peeling and preparation of different sizes apple pops and rings. Apple pops $(28.08 \mathrm{~mm}$ diameter) and apple rings $(0.5 \mathrm{~cm}$ thickness $)$ were prepared and blanched for 30 seconds. The blanched apple pops and apple rings were osmotically dehydrated in hypertonic solution (sugar and honey) at $70^{\circ}$ Brix. A known weight fruits were treated with different treatments. The osmosis was carried to optimize the osmotic time at different time interval $(1,2,3,4,5,6$, 7,8 , and $9 \mathrm{~h}$ ) at 1:3 ratio. The sizes having optimum osmosis were standardized on the basis of drying time. Further from osmo-dried apple pops and apple rings, apple choco shots and apple pie were prepared respectively.

\section{Physico-chemical analysis}

Physico-chemical analysis of fresh apple and osmo-dried apple pops, apple rings, apple choco shots, apple pie was conducted by using standard analytical procedures (Ting and Rouseff 1986; AOAC 1996; Ranganna 2009).

Total soluble solids (TSS) content of fresh and processed products was determined by using hand refractometer and sugars were estimated by Lane and Eynon method as detailed by 
Ranganna (2009). Acidity was determined by titrating the aliquots against $0.1 \mathrm{~N} \mathrm{NaOH}$ to a pink end point using phenolphthalein as an indicator (Ranganna 2009). Total phenols were extracted in $80 \%$ ethanol and were estimated using Folin-Ciocalteau reagent (AOAC 1996). The antioxidant activity was analyzed by free radical scavenging activity (Brand-Williams et al., 1995). Energy value of the developed products was measured in bomb calorimeter (Model Toshiwal DT-100), which is based on the principle that the amount of heat produced by burning the sample must be equal to the amount of heat absorbed by calorimeter assembly (Kays and Barton, 2002). Further, the non-enzymatic browning (NEB) was determined at 440nm using $60 \%$ aqueous alcohol as blank in spectrometer (Spectronic-20).

\section{Water loss (WL) or (Mass transfer) (Sharma et al., 1998)}

Water loss was the net loss at time $\mathrm{T}$ on an initial mass basis and expressed as in percentage. Water loss in fruits was calculated by using the following formula:

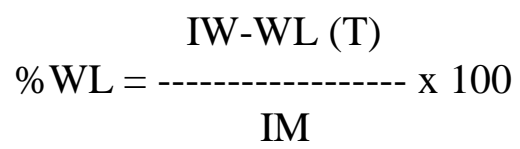

Where,

IW = Initial water content

WL $(\mathrm{T})=$ Water loss at time $\mathrm{T}$

$\mathrm{IM}=$ Initial mass of the sample

Solid gain (SG) or (Mass transfer) (Sharma et al., 1998)

The solid gain was the net sugar transported into the fruits on an initial mass basis and expressed in percentage.

$\% \mathrm{SG}=\% \mathrm{WL}-\% \mathrm{MR}$
Where,

$\mathrm{WL}=$ Water loss

$\mathrm{MR}=$ Mass reduction

The cost of production of apple pops, apple rings, apple choco shots and apple pie was worked out by calculating the cost of raw materials used and after adding processing charges and 20 percent profit.

\section{Statistical analysis}

The data on chemical characteristics of fresh and processed products were analyzed statistically by following Completely Randomized Design (CRD) detailed by Cochran and Cox (1992). Triplicate determinations were made for each attributes.

\section{Results and Discussion}

Physico-chemical characteristics of fresh apple (Golden delicious) and multiforal honey are presented in Table 1 . The fresh fruits are found to contain high moisture content $(83.90$ $\pm 0.10 \%)$ and low titratable acidity of $0.40 \pm$ 0.01 percent with ascorbic acid $(8.90 \pm 0.10$ $\mathrm{mg} / 100 \mathrm{~g})$, total phenols $(32.50 \pm 0.20$ $\mathrm{mg} / 100 \mathrm{~g})$, flavonoid content $(10.00 \pm 0.50 \%)$, antioxidant activity $(35.50 \pm 0.20 \%)$ with non-enzymatic content $(0.02 \pm 0.02)$. Crude fibre and total ash were found to be $3.00 \pm$ 0.50 and $2.42 \pm 0.02$ per cent. Similar results were reported by Sharma et al., (1998), Abdualrahman (2015) and Drogoudi and Pantelidis (2011).

Further, the total soluble solids of fresh honey were $70^{\circ} \mathrm{B}$ which was more than the values observed by Lakhanpal and Vaidya (2015) and was less than the observations of Kaushik et al., (1993). The free acid, lactose, total acid content in meq per $100 \mathrm{~g}$ was 3.60, 0.98 and 4.47 respectively which were slightly higher as recorded by Singh and Kaur (1998) and 
Kaushik et.al. (1993). The fructose and glucose content of honey observed were 35.85 per cent and 30.24 per cent which was in the same range as observed by Singh (1994) and Singh and Kaur (1998). Further, the HMF content observed were $9.35 \mathrm{mg} / \mathrm{kg}$ which was lower as reported by Lakhanpal and Vaidya (2015), Bulut and Kilic (2009).

\section{Optimization of dipping time}

Different dipping times (1-4 hours) were tried for osmotic dehydration of apple pops and rings in sugar and honey. Table 2 represents the optimization of osmosis dipping time for apple pops in sugar syrup and honey. The percent weight loss, volume gain, increase in TSS of pops and decrease in TSS of syrup was recorded after each hour and found constant after three hours in sugar and after four hours in honey. The dipping of pops in sugar syrup for three hours resulted in $30.6 \%$ weight loss with $6.66 \%$ gain in syrup volume, $47.6 \%$ increase in pops TSS with $14.2 \%$ decrease in TSS of syrup. However, four hours dipping of pops in honey resulted in $32.8 \%$ weight loss with $5.71 \%$ gain in syrup volume, $57.8 \%$ increase in pops TSS with $12.7 \%$ decrease in TSS of syrup. Henceforth, three hours dip of apple pops in sugar and four hours dip in honey optimized for proper osmosis. Nadia et al., (2013) reported the higher water loss and solids gain at $40^{\circ} \mathrm{C}$ in pears. Noroes et al., (2010) observed higher water loss and solid gain at the beginning of the osmosis and also reported maximum values at 3.5 hours $\left(65^{\circ} \mathrm{B}\right.$ sugar syrup) for guava. Whereas, maximum sugar penetration was observed during first 2 hours in apple slices by Morrera and Sereno (2001). Sagar and Kumar (2009) and Nowakunda et al., (2004) also reported similar results in mango and banana slices.

Similarly, dipping time for apple rings in sugar and honey syrup is presented in Table 3. The dipping of rings in sugar syrup for three hours resulted in $37.6 \%$ weight loss with $8.57 \%$ gain in syrup volume, $23 \%$ increase in TSS of rings with $17.1 \%$ decrease in TSS of syrup. However, four hours dipping of apple rings in honey resulted in $52.7 \%$ weight loss with $14 \%$ gain in syrup volume, $24.8 \%$ increase in rings TSS with $14.2 \%$ decrease in TSS of syrup. Henceforth, three hours dipping time for apple rings (sugar) and four hours dipping time for apple rings (honey) optimized for proper osmosis. Further, the drying time of 8 hours for apple pops (sugar), 7 hours for apple pops (honey), 5 hours for apple rings (sugar) and 4 hours for apple rings (honey) has been optimized and standardized. Seiiedlou et al., (2010) also observed that moisture content of samples decreases exponentially with the drying time and increased with increasing the drying air temperature and velocity. Similar results were observed by Figiel (2007) in apple cubes.

\section{Quality characteristics of fresh osmo-dried apple pops and rings (Fig. 1)}

On the basis of physico chemical characteristics of honey and sugar dipped apple pops and rings, the osmotic dehydration in honey was found better as compared to sugar (Table 4). The apple pops and rings dipped in honey found to contain 6.72$6.73 \mathrm{mg} / 100 \mathrm{~g}$ ascorbic acid, $65 \mathrm{mg} / 100 \mathrm{~g}$ phenols, 68.20-72\% flavonoids with 90.10$90.30 \%$ antioxidants. The phenol content of apple pops in sugar and honey was found to be 24.00 and $65.00 \mathrm{mg} / 100 \mathrm{~g}$ whereas apple rings in sugar and honey contains 24.02 and 65.00 $\mathrm{mg} / 100 \mathrm{~g}$ phenols respectively.

The water activity of sugar osmo-dried apple pops and rings was high as compare to honey osmo-dried apple pops and rings. On the other hand the non-enzymatic browning of sugar osmo-dried apple pops and rings was found lower as compare to honey osmo-dried apple pops and rings. 


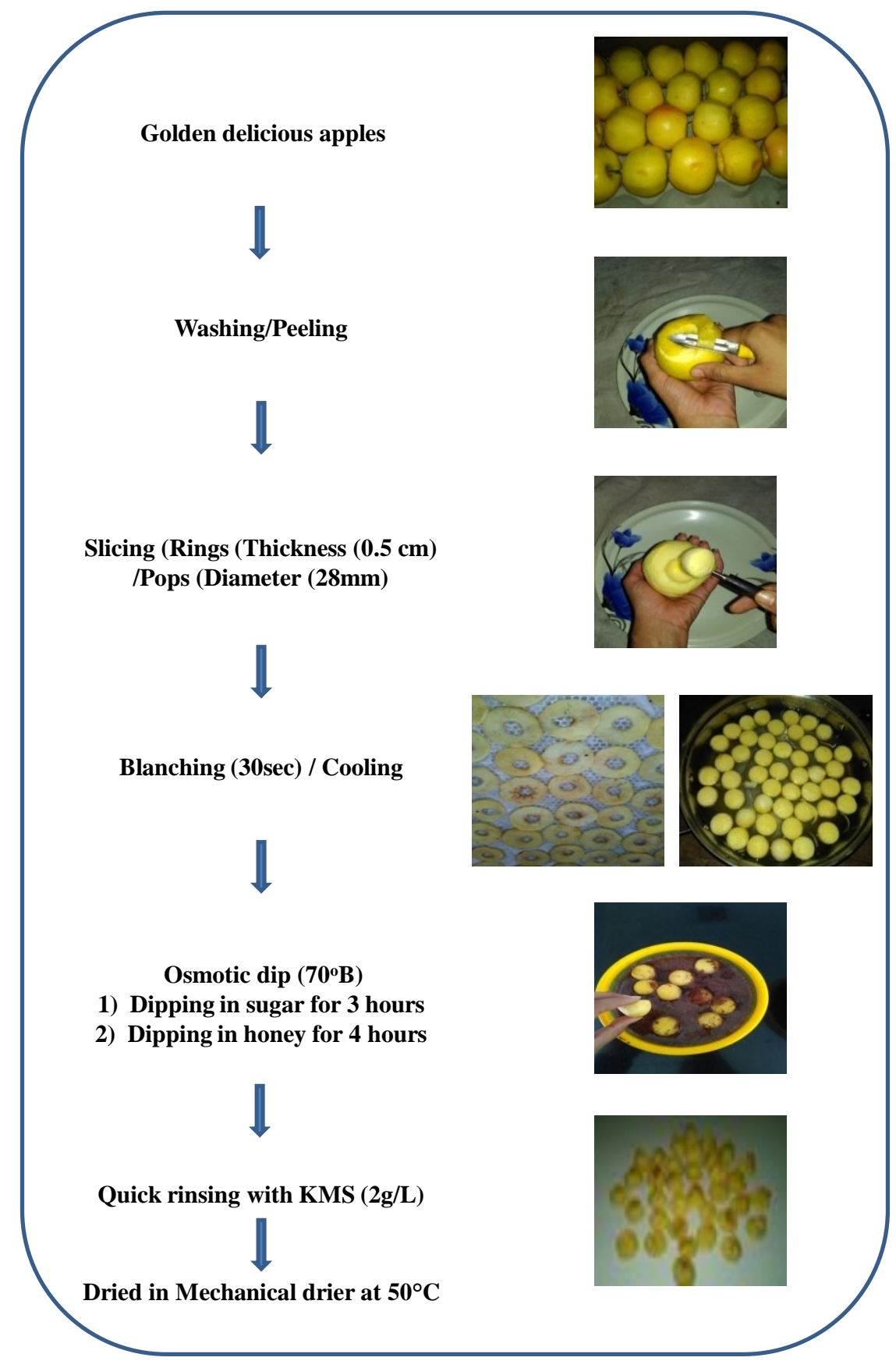

Fig.1 Flow sheet for osmotic dehydration of apple pops and apple rings 


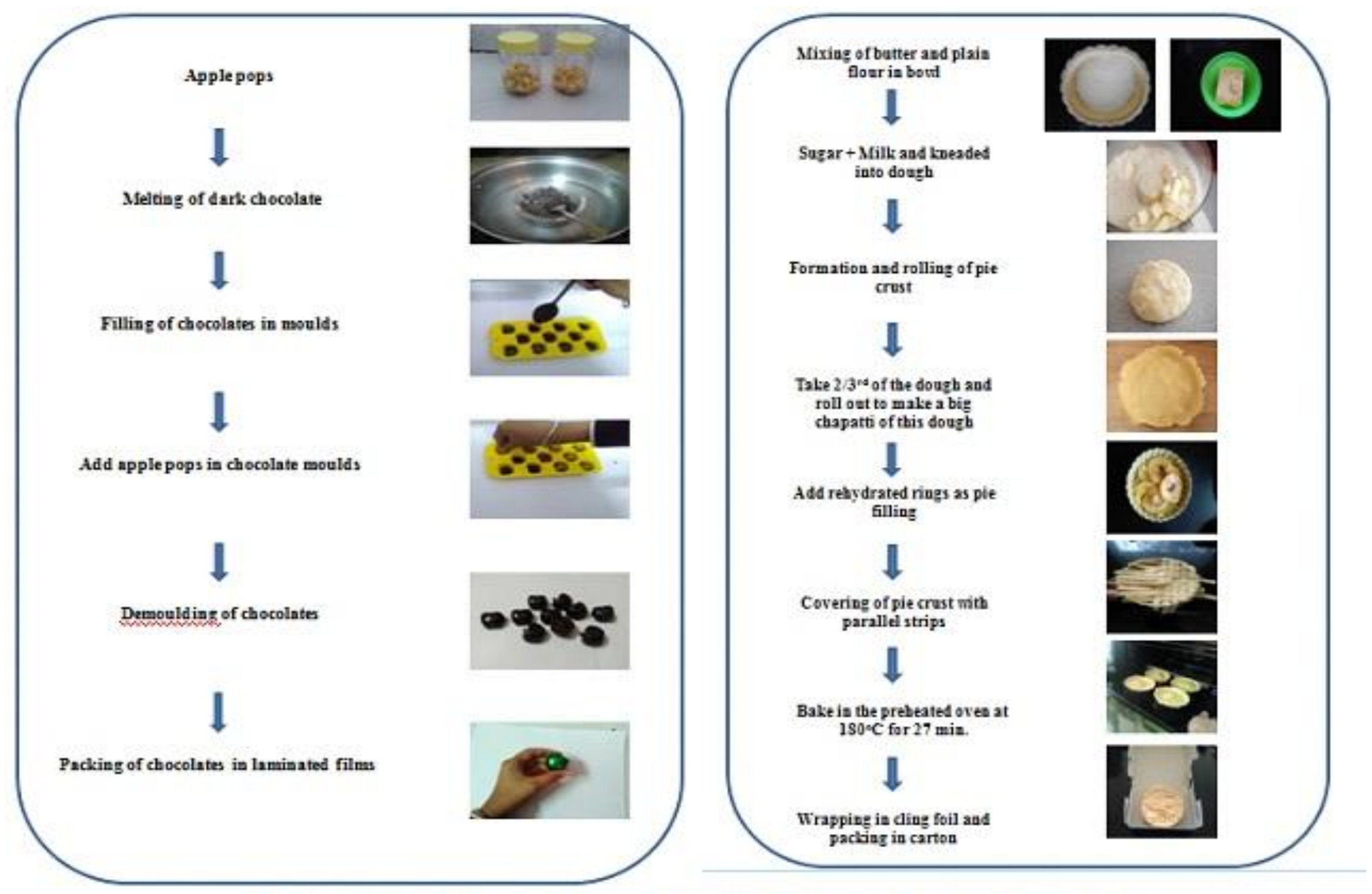

Fig 2: Flow sheet of preparation of apple choco shots and pie 
Table.1 Chemical characteristics of apple and multifloral honey

\begin{tabular}{|c|c|c|c|c|}
\hline S. No. & Parameter & Fresh apple & Parameter & Honey \\
\hline 1 & Moisture content $(\%)$ & $83.90 \pm 0.10$ & Total soluble solids $\left({ }^{\circ} \mathrm{B}\right)$ & $70.00 \pm 1$ \\
\hline 2. & Ash content $(\%)$ & $2.42 \pm 0.02$ & Free acid $(\mathrm{meq} / 100 \mathrm{~g})$ & $3.60 \pm 0.2$ \\
\hline 3. & Titratable acidity (\%) & $0.40 \pm 0.01$ & Lactone $(\mathrm{meq} / 100 \mathrm{~g})$ & $0.98 \pm 0.01$ \\
\hline 4. & Total soluble solids $\left({ }^{\circ} \mathrm{B}\right)$ & $15.00 \pm 1.53$ & Total acid (meq/100g) & $4.47 \pm 0.01$ \\
\hline 5. & Reducing sugars (\%) & $5.00 \pm 0.50$ & $\mathrm{pH}$ & $3.86 \pm 0.02$ \\
\hline 6. & Non reducing sugar (\%) & $3.16 \pm 0.02$ & Reducing sugars (\%) & $59.30 \pm 0.1$ \\
\hline 7. & Total sugars $(\%)$ & $8.33 \pm 0.02$ & Non-reducing sugars (\%) & $5.74 \pm 0.01$ \\
\hline 8. & Crude fiber $(\%)$ & $3.00 \pm 0.50$ & Total sugars $(\%)$ & $65.34 \pm 0.01$ \\
\hline 9. & Ascorbic acid(mg/100g) & $8.90 \pm 0.10$ & Moisture (\%) & $16.5 \pm 0.2$ \\
\hline 10. & Phenols (mg/100g) & $32.50 \pm 0.20$ & Total solids (\%) & $83.5 \pm 0.1$ \\
\hline 11. & Water activity $\left(\mathrm{a}_{\mathrm{w}}\right)$ & $1.00 \pm 0.50$ & Ash (\%) & $0.19 \pm 0.01$ \\
\hline 12. & Flavonoids (\%) & $10.00 \pm 0.50$ & Fructose $(\%)$ & $35.85 \pm 0.01$ \\
\hline 13. & Antioxidants (\%) & $35.50 \pm 0.20$ & Glucose $(\%)$ & $30.24 \pm 0.01$ \\
\hline 14. & Non enzymatic Browning (440nm) & $0.02 \pm 0.01$ & Glucose: Fructose ratio & $1.18 \pm 0.01$ \\
\hline 15. & & & Diastase Number (DN) & $20.50 \pm 0.1$ \\
\hline 16. & & & Total phenols $(\mathrm{mg} / 100 \mathrm{~g})$ & $65.45 \pm 0.02$ \\
\hline 17. & & & $\operatorname{HMF}(\mathrm{mg} / \mathrm{kg})$ & $9.35 \pm 0.01$ \\
\hline
\end{tabular}

Table.2 Optimization of osmo dipping time for apple pops

\begin{tabular}{|c|c|c|c|c|c|c|c|c|}
\hline \multirow{2}{*}{ Hours } & \multicolumn{2}{|c|}{$\begin{array}{l}\text { (\%) Weight loss } \\
\text { in pops }\end{array}$} & \multicolumn{2}{|c|}{$\begin{array}{l}\text { (\%) Volume } \\
\text { gain in syrup }\end{array}$} & \multicolumn{2}{|c|}{$\begin{array}{c}\text { (\%) Increases in } \\
\text { TSS of pops }\end{array}$} & \multicolumn{2}{|c|}{$\begin{array}{l}\text { (\%) Decrease in } \\
\text { TSS of syrup }\end{array}$} \\
\hline & $\begin{array}{l}\text { Sugar } \\
\mathbf{7 0}^{\circ} \mathrm{B}\end{array}$ & $\begin{array}{c}\text { Honey } \\
\mathbf{7 0}^{\circ} \mathrm{B}\end{array}$ & $\begin{array}{l}\text { Sugar } \\
{70^{\circ} \mathrm{B}}^{-}\end{array}$ & $\begin{array}{c}\text { Honey } \\
\mathbf{7 0}^{\circ} \mathrm{B}\end{array}$ & $\begin{array}{l}\text { Sugar } \\
70^{\circ} \mathrm{B}\end{array}$ & $\begin{array}{c}\text { Honey } \\
{70^{\circ} \mathrm{B}}^{\circ}\end{array}$ & $\begin{array}{l}\text { Sugar } \\
{70^{\circ} \mathrm{B}}^{2}\end{array}$ & $\begin{array}{c}\text { Honey } \\
70^{\circ} \mathrm{B}\end{array}$ \\
\hline 1 & 23.5 & 21.1 & 2.22 & 1.42 & 28.5 & 21.0 & 8.57 & 8.57 \\
\hline 2 & 29.8 & 25.6 & 4.44 & 2.85 & 38.0 & 31.5 & 11.4 & 11.4 \\
\hline 3 & 30.6 & 27.8 & 6.66 & 4.28 & 47.6 & 42.1 & 14.2 & 14.2 \\
\hline 4 & 30.6 & 32.8 & 6.66 & 5.71 & 47.6 & 57.8 & 14.2 & 17.1 \\
\hline \multirow[t]{2}{*}{ CD 0.05} & 0.070 & 0.070 & 0.008 & 0.007 & 0.263 & 0.353 & 0.127 & 0.178 \\
\hline & \multicolumn{2}{|c|}{ NS } & \multicolumn{2}{|c|}{ NS } & \multicolumn{2}{|c|}{0.001} & \multicolumn{2}{|c|}{0.001} \\
\hline
\end{tabular}

Table.3 Optimization of osmo dipping time for apple rings

\begin{tabular}{|c|c|c|c|c|c|c|c|c|}
\hline \multirow{2}{*}{$\begin{array}{l}\text { Karameters } \\
\text { Hours }\end{array}$} & \multicolumn{2}{|c|}{$\begin{array}{l}\text { (\%) Weight loss } \\
\text { in rings }\end{array}$} & \multicolumn{2}{|c|}{$\begin{array}{l}\text { (\%) Volume } \\
\text { gain in syrup }\end{array}$} & \multicolumn{2}{|c|}{$\begin{array}{l}\text { (\%) Increase in } \\
\text { TSS of rings }\end{array}$} & \multicolumn{2}{|c|}{$\begin{array}{l}\text { (\%) Decrease in } \\
\text { TSS of syrup }\end{array}$} \\
\hline & $\begin{array}{l}\text { Sugar } \\
70^{\circ} \mathrm{B}\end{array}$ & $\begin{array}{c}\text { Honey } \\
70^{\circ} \mathrm{B}\end{array}$ & $\begin{array}{l}\text { Sugar } \\
{70^{\circ} \mathrm{B}}^{2}\end{array}$ & $\begin{array}{c}\text { Honey } \\
70^{\circ} \mathrm{B}\end{array}$ & $\begin{array}{c}\text { Sugar } \\
{70^{\circ} \mathrm{B}}^{2}\end{array}$ & $\begin{array}{c}\text { Honey } \\
{70^{\circ} \mathrm{B}}^{\circ}\end{array}$ & $\begin{array}{c}\text { Sugar } \\
{70^{\circ} \mathrm{B}}^{2}\end{array}$ & $\begin{array}{c}\text { Honey } \\
70^{\circ} \mathrm{B}\end{array}$ \\
\hline 1 & 35.1 & 28.0 & 2.77 & 4.00 & 7.69 & 8.57 & 11.4 & 10.0 \\
\hline 2 & 36.3 & 37.5 & 5.71 & 8.00 & 15.3 & 14.2 & 14.2 & 11.4 \\
\hline 3 & 37.6 & 49.2 & 8.57 & 12.0 & 23.0 & 20.0 & 17.1 & 12.8 \\
\hline 4 & 37.6 & 52.7 & 8.57 & 14.0 & 23.0 & 24.8 & 17.1 & 14.2 \\
\hline CD 0.05 & 0.081 & 0.262 & 0.018 & 0.348 & 0.362 & 0.297 & 0.176 & 0.264 \\
\hline
\end{tabular}


Table.4 Quality characteristics of osmo-dried apple pops and rings

\begin{tabular}{|c|c|c|c|c|c|c|c|}
\hline \multirow{3}{*}{$\begin{array}{l}\text { Sr. } \\
\text { No }\end{array}$} & \multirow[t]{3}{*}{ Parameter } & \multicolumn{6}{|c|}{ Observations } \\
\hline & & \multicolumn{2}{|c|}{ Apple pops } & \multirow{2}{*}{$\begin{array}{l}\text { CD } \\
0.05\end{array}$} & \multicolumn{2}{|c|}{ Apple rings } & \multirow[t]{2}{*}{$\mathrm{CD}_{0.05}$} \\
\hline & & $\begin{array}{c}\text { Sugar } \\
\mathbf{7 0}^{\circ} \mathrm{B}\end{array}$ & $\begin{array}{l}\text { Honey } \\
70^{\circ} \mathrm{B}\end{array}$ & & $\begin{array}{c}\text { Sugar } \\
70^{\circ} \mathrm{B}\end{array}$ & $\begin{array}{c}\text { Honey } \\
70^{\circ} \mathrm{B}\end{array}$ & \\
\hline 1 & Moisture content (\%) & 11.50 & 8.00 & 1.020 & 8.60 & 5.00 & 1.020 \\
\hline 2. & Ash content $(\%)$ & 1.50 & 2.00 & 0.510 & 1.50 & 2.00 & 0.382 \\
\hline 3. & Titratable acidity (\%) & 0.368 & 0.582 & 0.003 & 0.368 & 0.570 & 0.024 \\
\hline 4. & $\begin{array}{l}\text { Total soluble solids } \\
\left({ }^{\circ} \mathrm{B}\right)\end{array}$ & 63.20 & 65.80 & 0.126 & 64.00 & 65.20 & 0.499 \\
\hline 5. & Reducing sugars (\%) & 18.60 & 65.70 & 0.126 & 18.64 & 65.74 & 0.027 \\
\hline 6. & $\begin{array}{l}\text { Non reducing sugar } \\
(\%)\end{array}$ & 50.57 & 5.22 & 0.015 & 50.58 & 5.25 & 0.021 \\
\hline 7. & Total sugars (\%) & 71.83 & 71.20 & 0.024 & 71.88 & 71.27 & 0.014 \\
\hline 8. & Crude fiber (\%) & 0.170 & 0.190 & 0.013 & 0.170 & 0.200 & 0.025 \\
\hline 9. & $\begin{array}{l}\text { Ascorbic acid } \\
(\mathrm{mg} / 100 \mathrm{~g})\end{array}$ & 5.60 & 6.72 & 0.102 & 5.62 & 6.73 & 0.013 \\
\hline 10. & Phenols (mg/100g) & 24.00 & 65.00 & 1.912 & 24.02 & 65.00 & 0.625 \\
\hline 11. & Water activity $\left(\mathrm{a}_{\mathrm{w}}\right)$ & 0.617 & 0.505 & 0.001 & 0.620 & 0.510 & 0.025 \\
\hline 12. & Flavonoids (\%) & 62.40 & 68.20 & 0.080 & 66.00 & 72.00 & 0.637 \\
\hline 13. & Antioxidants (\%) & 79.09 & 90.30 & 0.225 & 75.98 & 90.10 & 0.160 \\
\hline $\begin{array}{c}14 \\
.\end{array}$ & $\begin{array}{l}\text { Non enzymatic } \\
\text { Browning }(440 \mathrm{~nm})\end{array}$ & 0.041 & 0.126 & 0.001 & 0.050 & 0.114 & 0.014 \\
\hline
\end{tabular}

Table.5 Quality characteristics of apple choco shots and apple pie

\begin{tabular}{|c|c|c|c|c|c|c|c|}
\hline \multirow[t]{3}{*}{ S. No } & \multirow[t]{3}{*}{ Parameters } & \multicolumn{6}{|c|}{ Observations } \\
\hline & & \multicolumn{2}{|c|}{ Apple choco shots } & \multirow{2}{*}{$\mathrm{CD}_{0.05}$} & \multicolumn{2}{|c|}{ Apple pie } & \multirow{2}{*}{$\mathrm{CD}_{0.05}$} \\
\hline & & $\begin{array}{c}\text { Sugar } \\
70^{\circ} \mathrm{B}\end{array}$ & $\begin{array}{c}\text { Honey } \\
7^{\circ} \mathrm{B}\end{array}$ & & $\begin{array}{c}\text { Sugar } \\
70^{\circ} \mathrm{B}\end{array}$ & $\begin{array}{c}\text { Honey } \\
\mathbf{7 0}^{\circ} \mathrm{B}\end{array}$ & \\
\hline 1. & $\begin{array}{l}\text { Water activity } \\
\left(\mathbf{a}_{W}\right)\end{array}$ & 0.587 & 0.487 & 0.001 & 0.827 & 0.787 & 0.001 \\
\hline 2. & $\begin{array}{l}\text { Energy } \\
\text { (Kcal/100g }\end{array}$ & 418.08 & 430.09 & 0.458 & 255.86 & 260.74 & 0.240 \\
\hline 3. & Protein $(\%)$ & 5.84 & 5.88 & 0.014 & 9.30 & 9.32 & NS \\
\hline 4. & Crude fibre (\%) & 0.73 & 0.72 & 0.006 & 1.48 & 1.48 & 0.013 \\
\hline 5. & Fat content $(\%)$ & 31.00 & 31.00 & NS & 14.00 & 14.05 & NS \\
\hline 6. & Ash content (\%) & 1.65 & 2.15 & 0.013 & 1.20 & 1.23 & NS \\
\hline 7. & $\begin{array}{l}\text { Carbohydrates } \\
(\%)\end{array}$ & 60.78 & 60.25 & 0.058 & 74.02 & 73.84 & NS \\
\hline
\end{tabular}


Table.6 Cost of production of apple pops and apple rings

\begin{tabular}{|c|c|c|c|c|c|c|c|c|c|}
\hline \multirow{3}{*}{$\begin{array}{c}\text { Ingradie } \\
\text { nts }\end{array}$} & \multirow{3}{*}{$\begin{array}{l}\text { Rate } \\
\text { (Rs.) }\end{array}$} & \multicolumn{4}{|c|}{ Apple pops (2g) } & \multicolumn{4}{|c|}{ Apple rings (4g) } \\
\hline & & \multicolumn{2}{|c|}{ Sugar } & \multicolumn{2}{|c|}{ Honey } & \multicolumn{2}{|c|}{ Sugar } & \multicolumn{2}{|c|}{ Honey } \\
\hline & & Quantity & Amount & Quantity & Amount & Quantity & Amount & Quantity & Amount \\
\hline Apple & $20 / \mathrm{kg}$ & $100 \mathrm{~kg}$ & 2000 & $100 \mathrm{~kg}$ & 2000 & $100 \mathrm{~kg}$ & 2000 & $100 \mathrm{~kg}$ & 2000 \\
\hline Sugar & $40 / \mathrm{kg}$ & $84 \mathrm{~kg}$ & 3360 & - & - & $84 \mathrm{~kg}$ & 3360 & - & - \\
\hline Honey & $200 / \mathrm{L}$ & - & - & $120 \mathrm{~L}$ & 24000 & - & - & $120 \mathrm{~L}$ & 24000 \\
\hline \multicolumn{2}{|l|}{ Total } & & 5360 & & 26000 & & 5360 & & 26000 \\
\hline \multicolumn{3}{|c|}{ Processing charges (15\%) } & 804 & & 3900 & & 804 & & 3900 \\
\hline \multicolumn{3}{|c|}{ Total cost } & 6124 & & 29900 & & 6124 & & 29900 \\
\hline \multicolumn{3}{|c|}{$\begin{array}{l}\text { Recovery of syrup* } \\
\text { (cost reduced@70\% of sugar/ } \\
\text { honey cost) }\end{array}$} & 2352 & & 16800 & & 2352 & & 16800 \\
\hline \multicolumn{3}{|c|}{ Cost of production } & 3772 & & 13100 & & 3772 & & 13100 \\
\hline \multicolumn{3}{|c|}{ Profit $(20 \%)$} & 754.40 & & 2620 & & 1224.80 & & 5980 \\
\hline \multicolumn{3}{|c|}{ Total cost of production } & 4526.40 & & 15720 & & 4526.40 & & 15720 \\
\hline \multicolumn{3}{|c|}{ Yield, (No's pops/rings) } & 6000 & & 6000 & & 8000 & & 8000 \\
\hline \multicolumn{3}{|c|}{ Cost of 1 pop/ring } & $\operatorname{Re} 0.75$ & & Rs2.62 & & $\operatorname{Re} 0.57$ & & Rs1.96 \\
\hline
\end{tabular}

*syrup recovered has been utilized for further product developments (drinks etc)

Table.7 Cost of production of apple choco shots and apple pie

\begin{tabular}{|c|c|c|c|c|c|c|c|c|c|}
\hline \multirow[t]{3}{*}{ Ingredients } & \multirow[t]{3}{*}{ Rate (Rs.) } & \multicolumn{4}{|c|}{ Apple choco shots (13g) } & \multicolumn{4}{|c|}{ Apple pie (100g) } \\
\hline & & \multicolumn{2}{|c|}{ Sugar } & \multicolumn{2}{|c|}{ Honey } & \multicolumn{2}{|c|}{ Sugar } & \multicolumn{2}{|c|}{ Honey } \\
\hline & & $\begin{array}{c}\text { Quantit } \\
y\end{array}$ & $\underset{t}{\operatorname{Amoun}}$ & $\begin{array}{c}\text { Quantit } \\
y\end{array}$ & $\underset{t}{\text { Amoun }}$ & $\begin{array}{c}\text { Quantit } \\
y\end{array}$ & Amount & $\begin{array}{c}\text { Quantit } \\
y\end{array}$ & Amount \\
\hline $\begin{array}{l}\text { Apple pop } \\
\text { (Sugar) }\end{array}$ & $0.75 / \mathrm{p}$ & 6000 & 4500 & - & - & - & - & - & - \\
\hline $\begin{array}{l}\text { Apple pop } \\
\text { (Honey) }\end{array}$ & $2.62 / \mathrm{p}$ & - & - & 6000 & 15720 & - & - & - & - \\
\hline Chocolate & $200 / \mathrm{Kg}$ & $60 \mathrm{Kg}$ & 12000 & $60 \mathrm{Kg}$ & 12000 & - & - & - & - \\
\hline $\begin{array}{l}\text { LamiNSted } \\
\text { films }\end{array}$ & $\operatorname{Re} 0.50 / \mathrm{pc}$ & 6000 & 3000 & 6000 & 3000 & - & - & - & - \\
\hline $\begin{array}{l}\text { Apple ring } \\
\text { (Sugar) }\end{array}$ & $0.57 / \mathrm{p}$ & - & - & - & - & 8000 & 4560 & - & - \\
\hline $\begin{array}{l}\text { Apple ring } \\
\text { (Honey) }\end{array}$ & $1.96 / \mathrm{p}$ & - & - & - & - & - & - & 8000 & 15680 \\
\hline Maida & $30 / \mathrm{Kg}$ & - & - & - & - & $40 \mathrm{Kg}$ & 1200 & $40 \mathrm{Kg}$ & 1200 \\
\hline Butter & $250 / \mathrm{Kg}$ & - & - & - & - & $15 \mathrm{Kg}$ & 3750 & $15 \mathrm{Kg}$ & 3750 \\
\hline Milk & $45 / \operatorname{ltr}$ & - & - & - & - & 5 ltrs & 225 & 5 ltrs & 225 \\
\hline Sugar & $40 / \mathrm{kg}$ & - & - & - & - & $5 \mathrm{Kg}$ & 200 & $5 \mathrm{Kg}$ & 200 \\
\hline Packing & 3/pieces & - & - & - & - & 1000 & 3000 & 1000 & 3000 \\
\hline \multicolumn{2}{|c|}{ Total } & & 19500 & & 30720 & & 12935 & & 24055 \\
\hline \multicolumn{2}{|c|}{ Processing charges (15\%) } & & 2925 & & 4608 & & 1940 & & 3608 \\
\hline \multicolumn{2}{|c|}{ Cost of Production } & & 22425 & & 35328 & & 14875 & & 27663 \\
\hline \multicolumn{2}{|c|}{ Profit $(20 \%)$} & & 4485 & & 7066 & & 2975 & & 5533 \\
\hline \multicolumn{2}{|c|}{ Total Cost of Production } & & 26910 & & 42394 & & 17850 & & 33196 \\
\hline \multicolumn{2}{|c|}{ Yield (No's chocho shots/pie) } & 6000 & & 6000 & & 1000 & & 1000 & \\
\hline \multicolumn{2}{|c|}{ Cost of 1 shot/pie } & \multicolumn{2}{|c|}{ Rs. 4.49} & \multicolumn{2}{|c|}{ Rs. 7.06} & \multicolumn{2}{|c|}{ Rs. 17.85} & \multicolumn{2}{|c|}{ Rs. 33.20} \\
\hline
\end{tabular}


Quality characteristic of apple choco shot and pie (Fig. 2)

Apple choco shots were prepared from osmodried apple pops and apple pie from osmodried apple rings. The quality characteristics of apple choco shots and pie are presented in Table 5 shows an improved energy value of apple choco shots and pie dipped in honey syrup with energy value of 430.09 and 260.74 $\mathrm{Kcal} / 100 \mathrm{~g}$ as compared to 418.08 and 255.86 $\mathrm{Kcal} / 100 \mathrm{~g}$ in sugar dipped apple choco shots and pie respectively. The protein content of 5.84 and 5.88 percent was observed in apple choco shots and 9.30 and 9.32 percentin apple pie with sugar and honey respectively. Whereas, almost similar fat contents were observed in apple choco shots and pie with sugar and honey. The water activity of apple choco shots and pie (Sugar) and (Honey) was found $0.587,0.827$ and $0.487,0.7870 .827$ and $0.787 \mathrm{a}_{\mathrm{w}}$ respectively. These results are in agreement with Ayub et al., (2003).

\section{Cost of production}

The cost of production of apple pops (Sugar and honey) and apple rings (Sugar and honey) detailed in Table 6, apple choco shots (Sugar and honey) and apple pie (Sugar and honey) in Table 7 was calculated on the basis of current market prices of ingredients, nominal processing charges @15\% and reasonable profit margins @20\%. The cost of apple pops (Sugar and honey) was calculated to be Re 0.75 and Rs 2.62 and for apple rings (Sugar and honey) as $\operatorname{Re} 0.57$ and Rs 1.96 respectively. Further, the apple choco shots prepared from apple pops and apple pie from apple rings costs Rs 4.49 and Rs 17.85 with sugar and Rs 7.06 and Rs 33.20 with honey, respectively.

On the basis of results presented, it can be concluded that the apple fruits can be utilized for the preparation of osmo-dried apple pops and apple rings. These osmo-dried products can further be utilized for the development of apple choco shots and apple pie which are the new products in the market. Further, the use of honey for osmotic dehydration improves the nutritional quality of the developed products. Henceforth, the developed technology will be boon to apple processing industry and can be commercially explored at industry level for the production of quality value added products like osmo-dried apple pops and apple rings with apple choco shots and apple pie as novel products.

\section{References}

Abdualrahman May. 2015. Comparative study between local and imported apple (Malus domestica) fruits and their uses in juice production. Sci. Int. 3, 69-72.

Anonymous. 2016. Horticulture at a glance (State Department of Horticulture). http://www.hpagrisnet.gov.in/hpagris/H orticulture.

AOAC. 1996. Official Methods of Analysis of the Association of official Analytical chemist, Hortwits W (ed). Assoc Official Anal. Chemists, Washington, D. C. US.

Ayub M, Wahab $\mathrm{S}$ and Durrani $\mathrm{Y}$. 2003.Effect of water activity (aw), moisture content and total microbial count on the overall quality of bread. Int. J. Agric. Biol.5, 274-78.

Boyer J and Liu RH. 2004. Apple phytochemical and their health benefits. Nutr. J. 3, 5.

Brand-Williams W, Cuvelier ME and Berset C. 1995. Use of a free radical method to evaluate antioxidant activity. $L W T$ Food Sci. Technol. 28, 25-30.

Bulut L and Kilic M. 2009. Kinetics of hydroxyl methylfurfural accumulation and colour change in honey during storage in relation to moisture content. J. Food Proc. Preserv. 33, 22-32. 
Cochran WG and Cox GM. 1992. Experimental designs (2nd edn.). New York: Wiley.

Drogoudi PD and Pantelidis G. 2011. Effect of position on canopy and harvest time on fruit physico-chemical and antioxidant properties in different apple cultivars. Scientia Horticulturae, 129, 752-60.

Famurewa JAV, Oluwamukomi MO and Adenuga AL. 2006.Dehydration of osmosised red bell pepper (Capsicum апnит). Res. J. Biol. Sci.1, 36-39.

Farzaneh P, Fatemian H, Hosseini E, Asadi GH and Darvish F. 2011. A comparative study on drying and coating of osmotic treated apple rings. Int. J. Agricl. Sci. Res. 2, 57-66.

Figiel A. 2007. Dehydration of apple by a combiNStion of convective and vacuum-microwave drying. Pol. J. Food Nutr. Sci. 57, 131-35.

Kaushik R, Joshi VK and Gupta JK. 1993. Total soluble solids, acidity, $\mathrm{pH}$ and standard plate count in the Indian honey as affected by different treatments and storage conditions. J. Food Sci. Technol. 30, 442-43.

Kays SE and Barton FE. 2002. Rapid predication of gross energy and utilizable energy in cereal food products using Near-Infrared reflectance spectroscopy. J. Agric Food Chem. 50, 284-89.

Lakhanpal P and Vaidya D. 2015. Development and evaluation of honey based mango nectar. J. Food Sci. Technol. 52, 1730-35.

Lensrt A. 1996. Osmo-convective frying of fruits and vegetables- technology and application. Drying Technol. 14:391-41.

Morrera R and Sereno A M. 2001. Volumetric shrinkage of apple cylinders during osmotic dehydration. Proc. Int. Congress Engg. Food, 8, 1351-55.
Noroes ERV, Brasil IM, Lima JR, Bianchi M and Tau TG. 2010. Kinetics of the osmotic dehydration of guava. Acta Horticulturae, 864, 367-70.

Nowakunda K, Andres A and Fito P. 2004. Osmotic dehydration of baNSNS slices as a pretreatment for drying processes. Proc 14th Int Drying Symp. 2077-2083.

Nsdia DM, Nourhene BM, Nsbil K, Francis C and Catherine B. 2013. Effect of osmodehydration conditions on the quality attributes of pears. J. Food Proc. Preserv.256, 2157, doi:10.4172/21577110.1000256

Pedro NSR, De Oliveira E and Cadore S. 2006. Study of the mineral content of chocolate flavoured beverages. Food Chem.95, 94-100.

Ranganns S. 2009. Hand book of Analysis and Quality Control of Fruit and Vegetable Products. $4^{\text {th }}$ edn. Tata McGraw Hill, New Delhi.1112p.

Sagar VR and Kumar PS. 2009. Improvement of some process variables in mass transfer kinetics of osmotic dehydration of mango slices and storage stability. J Sci. Ind. Res. 68, 1043-48.

Seiiedlou S, Ghasemzadeh HR, Hamdami N, Talati F and Moghaddam M. 2010. Convective drying of apple: Mathematical modeling and determination of some quality parameters. Int. J. Agric. Biol. 12,17178.

Shah N, Khan M, Kasi A and Khair M. 2002. Post harvest and cold storage losses in apple of Balochistan. Asian J. Plant Sci. 1, 65-66.

Sharma KD, Sethi V and Maini SB. 1998. Changes in quality of osmo-vac dried apple slices on storage. J Sci. Ind. Res. 57, 393-98.

Singh B. 1994. Studies on the physicochemical characteristics of honey from important floral sources in Punjab. M.Sc. Thesis. PAU, Ludhiana. 
Singh N and Kaur BP. 1998. Relationship between heating \& hydroxymethyl furfural formation in different honey types. J. Food Sci. Technol. 35:154-56.

Ting SV and Rouseff RL. 1986. Citrus fruits and their products-analysis and technology. Marcel Dekker, Inc., New Delhi.293pp.

\section{How to cite this article:}

Babita Sharma, Devina Vaidya and Anil Gupta. 2018. Development of Novel Products from Osmo-Dried Apples: Apple Choco Shots and Apple Pie. Int.J.Curr.Microbiol.App.Sci. 7(09): 1999-2010. doi: https://doi.org/10.20546/ijcmas.2018.709.242 